\title{
CELIAC DISEASE: ROLE OF GENETICS AND IMMUNITY AND UPDATE ON NOVEL STRATEGIES FOR TREATMENT
}

\author{
Erica Sequeira', Ginpreet Kaur ${ }^{1}$, and Harpal S. Buttar ${ }^{2}$ \\ ${ }^{1}$ Department of Pharmacology, SPP School of Pharmacy and Technology Management, SVKM's \\ NMIMS, Mumbai, Maharashtra, India, and ${ }^{2}$ Therapeutic Products Directorate, Health Canada (Retd.), \\ Department of Pathology and Laboratory Medicine, Faculty of Medicine, University of Ottawa, Ontario, \\ Canada
}

Celiac disease (CD) is one of the most common inflammatory diseases of the small intestine which causes abdominal pain, diarrhoea, malabsorption, weight loss, anorexia, and iron deficiency anaemia in humans. It is a human leukocyte antigen (HLA)linked disorder that is triggered by the gluten and gliadin proteins from wheat and related cereals. The presence of other genetic factors such as HLA-DQ2 and HLA-DQ8 have also been identified for the generation of circulating autoantibodies to the enzyme transglutaminase (TG2). The TG2 enzyme deamidates the gluten peptides and increases their affinity for the HLA-DQ2 or $H L A-D Q 8$, which in turn cause a more vigorous activation of $C D 4^{+} T$-helper 1 (Th1) cells and trigger the immune response, and such immune cascade eventually leads to intestinal membrane damage and malabsorption. Generally, CD is managed by lifelong gluten-free diet. However, strict adherence to a gluten-free diet is difficult and is not always effective. Several pharmacological agents and alternative therapies for treating CD are currently under development and are in clinical trials, The purpose of this review is to highlight the complex involvement of genetics and immunity in $C D$ and to focus on the novel strategies being used for developing adjunct and alternative therapies for the treatment of CD.. Biomed Rev 2014; 25: 45-58

Key words: HLA-DQ2, HLA-DQ8, gluten, gliadin, intraepithelial lymphocytes, genetic predisposition

\section{INTRODUCTION}

Celiac disease (CD) is a one of the most common inflammatory disease of the small intestine that is triggered in genetically predisposed individuals by gluten and gliadin proteins present in wheat, barley, and rye. CD manifests in various degrees ranging from intraepithelial lymphocytosis to severe subepithelial mononuclear cell infilteration resulting in total villous atrophy coupled with crypt hyperplasia. Through autoantibody and biopsy screening, the incidence of $\mathrm{CD}$ in the United States and other Western and Middle Eastern countries was found to be between 1:70 and 1:200 in human popula-

Received 11 November 2014, revised 27 November 2014, accepted 5 December 2014

Correspondence to Dr Harpal S. Buttar, Department of Pathology \& Laboratory Medicine, Faculty of Medicine, 451 Smyth Road, Ottawa, Ontario, Canada K1H 8M5. Tel.: 613-824-1532, E-mail: hsbuttar@bell.net 
tion (1-8). Celiac disease is often found in conjugation with other autoimmune disorders such as type- 1 diabetes mellitus, autoimmune thyroiditis and dermatitis, herpetiformis and autoimmune alopecia (9). In addition, patients with longstanding undetected or untreated symptomatic CD are likely to be at a higher risk of developing the enteropathy-associated with T-cell lymphoma, small bowel adenocarcinoma and other cancers of the gastrointestinal tract (10-13). Generally, $\mathrm{CD}$ is linked with major histocompatibility complex class II genes and the alleles encoding the human leukocyte antigen molecules HLA-DQ2 and HLA-DQ8 and almost all patients with CD carry these HLA alleles (14). However, CD has a multifactorial inheritance. Therefore, its occurrence not only depends on specific mutations of a single gene but also can be caused by a combination of environmental factors and variations in multiple genes $(15,16)$. Also the viral infections altering intestinal permeability, gut microbiota, breast-fed infants and timing of gluten introduction in infant's diet has been implicated in the development of CD (17-19).

While some environmental factors play a role in causing $\mathrm{CD}$, gluten is one of the important players. Gluten-containing cereals have a high number of repetitive glutamine- and proline-rich sequences, thus making them highly resistant to proteolytic degradation by gastric, pancreatic, and intestinal brush-border enzymes, even in case of healthy individuals $(20,21)$. Such proteolytic resistance results in the persistence of relatively large peptides in the gastrointestinal tract, which activate the small-bowel mucosal immune system, thereby leading to the development of $\mathrm{CD}$ in genetically predisposed individuals. Under normal physiological conditions, the intestinal epithelium is fairly impermeable to long peptides. However, in undiagnosed or untreated $\mathrm{CD}$, the epithelial barrier function is compromised and gliadin peptides gain access across the epithelial layer and activate the immune system (22).

Currently, the available treatment of $\mathrm{CD}$ is a lifelong strict gluten-free diet, which helps to relieve symptoms in most cases and effectively prevent the potential malabsorption problems $(6,23-29)$. However, it is difficult to maintain the gluten-free diet schedule and such practice can lead to social isolation, since modern diets are heavily based on gluten containing products. The lifelong strict gluten-free diet can also have an adverse impact on the quality of life of patients $(30,31)$. There are many instances where the gluten-free diet has been contaminated with wheat flour $(32,33)$. Owing to all these disadvantages and ineffectiveness of gluten-free diet in some cases, there is an increased need of alternative new therapeutic approaches. These novel therapies are being developed for the management of $\mathrm{CD}$, based on the enhanced understanding of the pathogenic mechanisms that underline this disease.

\section{ROLE OF GENETICS AND IMMUNITY IN CELIAC DISEASE}

HLA class I and II genes map on the short arm of chromosome $6(6 \mathrm{p} 21.3)$ and codes for the cell surface antigen presenting proteins and thus play a major role in immunity $(34,35)$. HLA class I heterodimers are constituted of alpha-heavy chain that encodes the HLA-A, B and C loci and by small beta 2-microglobulin molecule whose gene maps on chromosome 15. HLA class II heterodimers that consists of alpha and beta chains are specified by genes in the HLA-D region that comprehends HLA-DP (DPA1 and DPB1), DQ (DQA1 and DQB1) and DR (DRA1 and DRB1) genes (36). Among the genetic markers, it is the HLA gene that seems to make greatest contribution to CD (37). The presence of the genes that are responsible for coding DQ2 and DQ8 molecules of HLA complex class II explains up to $40 \%$ of the occurrence of CD in European population (38). The association between DQ2 and DQ8 with CD is due to the high affinity of the DQ2 molecule of HLA towards the peptides- derived from gluten, which present them to the $\mathrm{T}$ lymphocytes (39). According to a multicenter study carried out in Europe, it was observed that the HLA DQ2 was present in about 86 to $93 \%$ of CD patients, while around 3 to $8 \%$ of these patients have DQ8 without DQ2 (40). Interestingly enough, these molecular markers are also carried by many individuals without $\mathrm{CD}$, for example, in 40 to $65 \%$ of first degree relatives of CD patients and 18 to $30 \%$ of the normal population (41-43). Thus, CD has a multifactorial inheritance factors, and does not depend on the mutations of a single gene but it is caused by a combination of environmental factors and variations in multiple genes. In recent years, genome-wide association studies (GWAS) have identified many non-HLA genes associated with an increased risk of $\mathrm{CD}$ as indicated in Table 1, such as those coding for cytokines, chemokines and their receptors, cell adhesion molecules, T- and B-cell activators.

The non-HLA genetic contribution to celiac disease is only $15 \%$ and these polymorphisms are not considered in the calculation of the genetic risk (36). The primary HLA-DQ association in $\mathrm{CD}$ was initially confirmed by experiments on $\mathrm{CD} 4^{+}$ $\mathrm{T}$ lymphocytes which were isolated from intestinal biopsies of patients who were able to recognize gluten peptides which were presented by DQ2.5/ DQ8 positive antigen presenting cells (60-63). The DQ2.5/DQ8 displays the highest affinity for the negatively charged amino-acids derived from the TG2 mediated deamidation (i.e. conversion of glutamine to glutamic 
Table 1. Non-HLA loci and genes of celiac disease susceptibility

\begin{tabular}{|c|c|c|c|}
\hline Loci identified & Origin of the cohort & Candidate genes & References \\
\hline CELIAC 2 5q31-q33 & $\begin{array}{l}\text { Italy, Finland, Scandinavia, } \\
\text { Europe }\end{array}$ & Unknown & $44-47$ \\
\hline $\begin{array}{l}\text { CELIAC } 32 \mathrm{2q} 33 \\
\text { CELIAC } 419 \mathrm{p} 13.1\end{array}$ & $\begin{array}{l}\text { France, The Netherlands, } \\
\text { Sweden, Norway } \\
\text { Netherland }\end{array}$ & $\begin{array}{l}\text { CTLA4 } \\
\text { Myosin IXB }\end{array}$ & $\begin{array}{l}48-50 \\
51\end{array}$ \\
\hline CELIAC 5 15q11.q13 & Finland & Unknown & 52 \\
\hline CELIAC 6 4q27 & $\begin{array}{l}\text { United Kingdom, } \\
\text { Netherland, Ireland, Italy, } \\
\text { Scandinavia, } \\
\text { United States }\end{array}$ & $\begin{array}{l}\text { KIAA1109 } \\
\text { TENR (AD AD 1) } \\
\text { IL2 } \\
\text { IL21 }\end{array}$ & $53-57$ \\
\hline CELIAC 7 1q31 & $\begin{array}{l}\text { United States, United } \\
\text { Kingdom, Italy, Ireland, } \\
\text { Netherland }\end{array}$ & RGS1 & $53,54,56,57$ \\
\hline CELIAC 8 2q11-q12 & $\begin{array}{l}\text { United Kingdom, Ireland, } \\
\text { Netherland }\end{array}$ & $\begin{array}{l}\text { IL18RAP } \\
\text { IL18R1 }\end{array}$ & $53,54,58$ \\
\hline CELIAC 9 3p21 & $\begin{array}{l}\text { United Kingdom, Ireland, } \\
\text { Spain, Netherland }\end{array}$ & $\begin{array}{l}\text { CCR1 } \\
\text { CCR2 } \\
\text { CCRL2 } \\
\text { CCR3 } \\
\text { CCR5 } \\
\text { XCR1 }\end{array}$ & $53,54,59$ \\
\hline CELIAC 10 3q25-q26 & $\begin{array}{l}\text { United Kingdom, United } \\
\text { States, Ireland, Italy, } \\
\text { Netherland }\end{array}$ & IL12A & $53,54,56,57$ \\
\hline CELIAC II SQLOC & $\begin{array}{l}\text { United Kingdom, United } \\
\text { States, Ireland, Italy, } \\
\text { Netherland }\end{array}$ & LPP & $53,54,56,57$ \\
\hline CELIAC 13 12q24 & $\begin{array}{l}\text { United Kingdom, Ireland, } \\
\text { Italy, Netherland } \\
\text { United Kingdom, United } \\
\text { States, Ireland, Italy, } \\
\text { Netherland }\end{array}$ & $\begin{array}{l}\text { TAGAP } \\
\text { SH2B }\end{array}$ & $\begin{array}{l}53,54,57 \\
53,54,56,57\end{array}$ \\
\hline
\end{tabular}


acid amino-acid) (64). This degree of affinity is dependent on the degree of interaction that occurs in the central region of nine amino-acid residues whose lateral positions are anchored to the positions $\mathrm{P}_{1}, \mathrm{P}_{4}, \mathrm{P}_{6}, \mathrm{P}_{7}$, and $\mathrm{P}_{9}$ into DQ-binding regions. Specifically, it is the DQ2.5 heterodimers that bind peptides with negatively charged side chains at P4, $\mathrm{P} 6$ and $\mathrm{P} 7$ positions while DQ8 molecules show only a preferential binding for the negatively charged residues at P1 and P9 (65). The role played by specific DQ heterodimers is being studied so as to understand the cause of the gluten-specific T-cell response in patients carrying other DQ molecules (not DQ2.5 or DQ8) (63, 66-68). Thus, it appears that the genetic predisposition to CD depends on one gene with a large effect (HLA-DQ2/ DQ8) on the adaptive immune response to gluten peptides and many other genes influencing different aspects of innate and adaptive immune reactions, intestinal permeability, and general predisposition to autoimmunity.

\section{HLA MOLECULAR TYPING}

So far, only HLA-DQA1 and HLA-DQB1 loci can be used in the clinical practice of CD (69). By itself, HLA test does not have a diagnostic significance but is mainly considered for its negative predictive value since $\mathrm{CD}$ is highly unlikely to occur when DQ predisposing alleles are absent; while a positive result only means a genetic predisposition for celiac autoimmunity (36). Although many individuals carry DQ2.5/ DQ8 molecules but they do not depict the disease and only some will develop gluten intolerance. Thus, it is vital that future clinical investigations should address to identify new markers, which can improve prediction of the disease in people who carry the same HLA at-risk alleles. Sequence Specific Primers-PCR, Reverse Dot Blot analysis and Real Time PCR have been used for HLA molecular typing, and recently, different commercial kits have been developed to specifically genotype CD-associated DQA1/DQB1 alleles $(70,71)$. Thus, HLA typing allows to define the $C D$ risk gradient associated with each particular HLA-DQ status and DQB1*02 homozygosity/heterozygosity $(72,73)$. HLA typing is routinely suggested by clinicians in dubious $\mathrm{CD}$ case, i.e., uncertain or discrepant serology and or biopsy $(74,75)$. It is useful in screening first degree relatives due to the high prevalence of $\mathrm{CD}$ in first degree relatives.

Almost all the patients with CD develop the immunoglobulin (Ig) A autoantibodies to TG2 enzyme. The TG2 is responsible for deamidation of glutamine to negatively charged glutamic acid residues $(76,77)$. Due to their high content in glutamine and neighbouring proline and hydrophobic amino acid residues, gluten proteins, are substrates for TG2 $(76,78)$. When deamidated, the affinity of the negatively charged gluten peptides to HLA-DQ2 or HLA-DQ8 increases which results in a vigorous T-cell activation. While the adaptive immune response to gluten is well established, the gluten proteins can elicit an innate immune response in professional antigenpresenting cells that activates predominantly the intraepithelial lymphocytes (IEL) but also the intestinal epithelial cells (7983). This innate immune response is an immediate reaction that appears to favour the development of adaptive immunity to gluten in patients who carry HLA-DQ2 or HLA-DQ8 (80). The innate immune activation of IELs by gluten induces the expression of the nonclassic class I molecule MICA on the intestinal epithelium which serves as a ligand for the heterodimeric NKG2D receptors.

It has been observed that epithelial MICA and up-regulated epithelial production of interleukin (IL)-15 leads to the activation of NKG2D on IELs (84). NKG2D also links the innate and adaptive immunity, because it triggers both antigen-specific lymphocyte mediated cytotoxicity and induces a direct cytolytic function independent of T-cell receptor (TCR) specificity in effector CD8 T cells (85). The central role of IL-15 in the activation of innate and adaptive immunity in $\mathrm{CD}$ has been confirmed by several investigators (86-90), along with an increased expression of IL-15 receptor and a lower threshold for activation on IEL(88). Recently, it was found that IL-21, which is produced by $\mathrm{CD} 4^{+} \mathrm{Th} 1 \mathrm{~T}$-cells, has emerged as an additional driving force to the innate immunity that often acts in concert with IL-15 (91). It is imperative to know the pathogenesis of CD because it is one of the important causes of malabsorption in humans. The data analyses of a clinical study using endoscopic and histological features of 94 consecutive patients over 12 years indicated that $C D$ is the most common cause of malabsorption followed by tropical sprue (92). According to this study, $85.7 \%$ of the patients with tropical sprue had normal duodenal folds, whereas $82 \%$ of the patients with $\mathrm{CD}$ had abnormal duodenal folds. Also, the scalloping of folds as well as both scalloping and attenuation of the duodenal folds was more frequently present in patients with $\mathrm{CD}$. On histological examination, it was observed that all the patients with CD had Marsh grade 3 villous atrophy, while only 11 patients with tropical sprue had Marsh grade 3 villous atrophy. Crypt hyperplasia was greater in $\mathrm{CD}$ than that of tropical sprue.

While increase in IELs were noted in all the biopsies, grade 3 IEL infiltrates were seen only in CD. The extent of epithelial cell damage in the biopsies was focal in $85.7 \%$ of the patients 
with tropical sprue, the extent of epithelial damage was mostly diffuse in those with $\mathrm{CD}$. In addition, the normal tall columnar epithelium shape was maintained in most patients with tropical sprue, but changed from normal tall columnar epithelium to cuboidal cells in $40.9 \%$ of patients with CD (92). The marked histopathologal differences observed between $\mathrm{CD}$ and tropical spruce patients should be taken into consideration while examining the duodenal biopsy samples or doing the endoscopic examination of the GI tract.

Celiac Disease has numerous symptoms as indicated in Table 2 . These symptoms vary with different people. These differences make the diagnosis of the disease difficult.

Table 2. Symptoms of celiac disease*

\begin{tabular}{|l|l|}
\hline $\begin{array}{l}\text { Gastrointestinal } \\
\text { symptoms }\end{array}$ & $\begin{array}{l}\text { Non-gastrointestinal } \\
\text { symptoms }\end{array}$ \\
\hline Diarrhoea & Iron deficiency anaemia \\
\hline Weight loss & Chronic pain \\
\hline Abdominal pain & Migraine \\
\hline Anorexia & Join pain/ inflammation \\
\hline Abdominal distension & Attention deficit disorder \\
\hline Lactose intolerance & Depression \\
\hline Abdominal distention & Epilepsy \\
\hline Irrtitability & Osteoporosis/ Osteopenia \\
\hline & $\begin{array}{l}\text { Infertility/ Recurrent fetal } \\
\text { loss }\end{array}$ \\
\hline & Autoimmune disorders \\
\hline & Delayed puberty \\
\hline
\end{tabular}

*From (93)

\section{THE INTERVENTION OF NOVEL THERAPIES}

As mentioned earlier, an efficient therapy for the patients suffering from $\mathrm{CD}$ is ideally the adherence to a strict gluten- free diet, which is difficult to maintain and comply with. Such restriction may not only interfere with many social activities, but may also limit the enjoyment of food varieties. Furthermore, patients who have a high level of gluten sensitivity are likely to be adversely affected by even small amounts of gluten in their foods which may be declared gluten-free. Therefore, exploration of alternative therapies or adjunctive treatments becomes necessary for the $\mathrm{CD}$ patients.

\section{WHEAT VARIANTS AND GENETIC MODIFICATION}

Wheat strains with low immunogenicity, i.e., decreased number of immunogenic T-cell epitopes can be selected from the already existing varieties or from the genetically modified wheat. By hybridization between tetraploid Triticum turgidum and the diploid Triticum tauschii, the hexaploid Triticum aestivum was generated. The tetraploid Triticum turgidum likely originated from the diploid Triticum monococcum and Triticum speltoides (94). The duodenal biopsy specimens from patients with celiac disease showed that ingestion of tetraploid wheat gluten caused reduced toxicity as opposed to the intake of hexaploid wheat (95). Similarly two other wheat varieties, one low in $\alpha$ - and $\beta$-gliadins and another low in $\alpha$-, $\beta$-, $\gamma$ - and $\boldsymbol{\omega}$-gliadins also showed decreased toxicity in duodenal biopsy specimens (96).

With the utilization of gluten-specific T-cell clones from duodenal biopsy specimens of CD patients and the identification of key immunogenic T-cell epitopes, including the antibodies directed to some of these epitopes, provided reproducible results for the characterization of less toxic wheat species. In silico approach was applied to analyze $230 \alpha$-gliadin sequences derived from ancestral halotypes for the presence of T-cell stimulatory epitopes that bind to HLA-DQ2/8. It was observed that all major immunogenic peptides are present in the DD genotype, except for $\alpha-9$ sequences in the AA genotype. The gluten digest from $T$. tauschii which contains the $\alpha$-gliadin sequences that is encoded by the DD genome elicited the strongest $\mathrm{T}$-cell response as compared to the gluten derived from the $\mathrm{AA}$ and $\mathrm{BB}$ genome species that lack these sequences were dampened $(97,98)$.

Genetic deletion of certain gliadin genes was analyzed in T. aestivum, which lacks one locus containing gluten genes. This was carried out by in silico analysis based on the known DNA sequences and by Western blotting with epitope specific antibodies (99). The results revealed that the complete deletion of the $\alpha$-gliadin locus on chromosome 6 led to a decrease in total T-cell stimulatory epitopes, however, it also impaired the baking properties of this wheat variety.

\section{PRETREATMENT OF FLOURS AND GERMINATION OF WHEAT}

Certain lactobacilli added to sourdough for fermentation are able to proteolyze the proline- or glutamine-rich gluten peptides and thus decrease the immunotoxicity (100-102). A pilot 
study done in $17 \mathrm{CD}$ patients suggested that the sourdough bread was well tolerated. Since the patients were challenged only for 2 days, hence it was difficult to draw any definitive conclusions from this very short period study (103). In a similar manner, intrinsic proteases are produced during germination of wheat, i.e., when the amino acids from the gluten storage proteins are being used by the growing plant. The germination process of wheat can degrade the immunogenic T-cell epitopes, and thus create nontoxic cereal product for patients suffering from CD (104). Another alternative would be to inactivate immunogenic gluten epitopes by exploiting the substrate specificity of TG2 that generates more potent gluten peptides via deamidation (105).

The treatment of wheat with low molecular weight microbial TG, derived from Streptomyces moboraensis, reduced the stimulatory effect of the flour on gluten reactive T-cells. Additionally, treatment of TG with these microbes improves loaf volume and crumb texture of breads (106). Nevertheless, caution is necessary since the treatment of flour with the microbial TG increased rather than decreasing the stimulation of gliadin-specific T-cells $(107,108)$. Thus, the future studies should focus on the development of cereals that are devoid of immunogenic epitopes along with conserving their baking qualities.

\section{ORAL ENZYME THERAPY}

Usually the complex proteins that reach the intestinal lumen are digested by gastric pepsin and pancreatic proteases and further degraded by the brush border enzymes into the simpler amino acids, dipeptides or tripeptides that are transported across the epithelial layer. The large quantity of proline residues in immunodominant gliadin peptides which make them highly resistant to the human digestive proteases (109111). Hence, in order to avoid those peptides from reaching the lamina propria, prolyl-endopeptidases (PEP) which are expressed in many microorganisms were used to cleave the immunodominant proline rich regions (112-116). A study was performed using PEP obtained from Flavobacterium meningosepticum admixed to a daily drink with 5 grams of gluten over 2 weeks, and it could prevent fat malabsorption and symptoms in some patients with previously diet controlled CD (117). However, the potency of the enzyme was not considered sufficient enough to draw any clear conclusions. The PEP from Aspergillus niger, which has a higher specific activity than PEP from Flavobacterium meningosepticum to inactivate the immunodominant gluten peptides may be tried $(118,119)$.

\section{INHIBITION OF INTESTINAL PERMEABILITY}

In healthy individuals, the tight junctions between the epithelial cells protect and control the exposure of the submucosal gastrointestinal tissues to the macromolecules which may be toxic. However, in patients with $\mathrm{CD}$ there is an increased intestinal permeability due to the opening of the tight junctions (zonulae occludentes), causing an increased influx of the gluten peptides into the subepithelial lamina propria and the T-cell response to gluten is triggered. Previous studies identified that the human protein zonulin, a precursor of prehaptoglobin-2, acts as a regulator of epithelial permeability and is highly expressed in $\mathrm{CD}$ and is likely a contributor to its pathology $(120,121)$. This protein is similar in effect to that of zonula occludens toxin (ZOT) expressed by Vibrio cholerae, which impairs epithelial tight junctions integrity (122). An octapeptide derived from ZOT (AT-1001) antagonises zonulin action via receptor blockade and thus protects tight junctional integrity (123). A pilot study was performed using AT-1001 in 14 patients with $\mathrm{CD}$ in remission and 7 controls who were challenged with a single dose of gluten for three consecutive days, and it was observed that the intestinal permeability remained intact (124). It appears that a complementary therapeutic approach and its combination with other treatments could be more effective for treating CD patients.

\section{TRANSGLUTAMINASE-2 INHIBITORS}

The use of transglutaminase-2 (TG-2) inhibitors is also one of the novel therapy because inhibiting the deamidation of the gliadin peptide decreases its affinity to HLA-DQ2 and HLA-DQ8 and consecutively decreases the T-cell stimulation. Many inhibitors that target the transglutaminase cross-linking activity have been developed and tested in vitro (125-128). There are several competitive inhibitors of TG-2 (putrescine, spermidine, histamine, monodansyl cadaverin, cadaverine, 5-pentylamine, fluoresceine, cystamine and cysteamine) (129); reversible inhibitors (mainly guanoside triphosphate analogues) (130) and irreversible inhibitors (iodoacetamide, 3-halo-4,5-dihydroisoxazoles, carbobenzyloxy-L-glutaminyl glycine derivatives, 6-diazo-5-oxo-norleucine, 2-[(2-oxopropyl)thio]imidazolium derivatives) $(131,132)$. Cystamine and 2-[(2-oxopropyl)thio]imidazolium inhibitors (L682777 or R283) have also been tested ex vivo in cultures of small intestinal biopsy specimens of patients with $\mathrm{CD}$ where there was a decrease in the T-cell stimulatory activity of gliadin peptides $(133,134)$. However, this therapeutic approach is risky, since transglutaminase plays many important roles in 
the body and the inhibitory agents have to be designed so that they specifically remain in the intestine and do not cross to the systemic circulation.

\section{HLA-DQ2 INHIBITORS}

Adaptive immunity in $\mathrm{CD}$ is activated due to the binding of the gliadin peptides onto the HLA-DQ2, thus blocking the DQ2 as an attractive target to prevent the immune activation. Modification of $\alpha$-gliadin so as to make it a partial agonist, significantly inhibited the IFN- $\gamma$ production as compared to the patients with $\mathrm{CD}$ having the unmodified peptide (135). Furthermore, replacement of leucine L11 and L18 residues in the $\alpha$-gliadin with sterically bulky groups retained the DQ2 affinity but decreased the T-cell recognition (136). Overall, if the designed inhibitors act locally in the gut and specific for gluten, it could constitute a potential therapeutic approach.

\section{ANTI-INFLAMMATORY COMPOUNDS}

One characteristic feature of $\mathrm{CD}$ is persistent inflammation of the intestinal tract. Treatment with corticosteroids and immunosuppressive agents have been considered. In a cohort study of 30 people, a combination of gluten-free diet and corticosteroids was found to be effective in treating the symptoms and healing of mucosal injury (137). Budesonide, a locally acting corticosteroid with minimal side effects when used in addition with gluten-free diet significantly improved the malabsorption symptoms (138). There also has been a report of mesalamine to treat the refractory sprue patients (139).

\section{IL-15 ANTAGONISTS}

An increased expression of IL-15 is responsible for the development of refractory $\mathrm{CD}$, since it induces the secretion of epithelial MICA that binds to NKG2D receptor located on the surface of intraepithelial lymphocytes. A study on transgenic mouse models with overexpression of IL-15 and consequent development of autoimmune enteropathy indicates that blocking antibody against IL-15 was capable of efficiently reversing the intestinal damage $(140,141)$. IL-15 blocking antibodies were able to decrease the number of intraepithelial lymphocytes that accumulated in the intestinal epithelium of human IL-15 transgenic mouse models (142).

\section{CXCL10 AND CXCR3}

It was found that the CXCL10 which is another T-cell recruiting chemokine that elicits its effects by binding to the receptor CXCR3 expressed by T-lymphocyte showed an increased expression in response to the gliadin stimulation of monocytes (143). These findings support the role of T cell-recruiting chemokines as a future therapeutic target not only for $\mathrm{CD}$ but also for gluten sensitivity in general (144).

\section{CONCLUSIONS}

In humans, $\mathrm{CD}$ is a leukocyte antigen (HLA)-linked disorder that is triggered by the gluten and gliadin proteins present in wheat, rye and barley. It appears that early humans didn't eat cereal grains, so people didn't evolve the ability to break down and digest gluten. Thus, in some subjects the body treats gluten as a toxin that triggers gut reactions. Globally, increased number of patients are diagnosed with $\mathrm{CD}$. This chronic inflammatory disease of the small intestine causes abdominal pain, diarrhoea, malabsorption, weight loss, anorexia, and iron deficiency anaemia.

Due to better understanding of the underlying pathology, there has been a development of adjunctive and even alternative therapeutic approaches that help effectively to manage or even cure this condition. Although several pharmacological agents for treating $\mathrm{CD}$ are currently under development and are in clinical trials, gluten-free diet still remains the only treatment option for these patients, who regardless of the social aspect lack any significant or potentially life threatening side effects. Therefore, in addition to therapeutic efficacy for reducing both CD symptoms and histological intestinal damage, the ideal alternative therapy to lifelong gluten withdrawal will need development of safe and efficacious products. This encouraging trend could gain momentum in the coming years.

\section{CONFLICT OF INTEREST}

The authors declare no conflict of interest.

\section{REFERENCES}

1. Abdulkarim AS, Murray JA. Celiac disease. Curr Treat Options Gastroenterol 2002;5:27-38.

2. Ciclitira PJ, King AL, Fraser JS. AGA technical review on Celiac Sprue. American Gastroenterological Association. Gastroenterology 2001;120:1526-1540.

3. Farrell RJ, Kelly CP. Celiac sprue. $N$ Engl J Med 2002;346:180-188.

4. Green PH, Cellier C. Celiac disease. $N$ Engl J Med 2007;357:1731-1743. DOI: 10.1056/NEJMra071600

5. Green PH, Jabri B. Coeliac disease. Lancet 2003;362:383391. 
6. Di Sabatino A, Corazza GR. Coeliac disease. Lancet 2009;373:1480-1493. DOI: 10.1016/S01406736(09)60254-3.

7. Fasano A, Berti I, Gerarduzzi T, Not T, Colletti RB, Drago $\mathrm{S}$, et al. Prevalence of celiac disease in at-risk and notat-risk groups in the United States: a large multicenter study. Arch Intern Med 2003;163:286-292.

8. Maki M, Mustalahti K, Kokkonen J, Kulmala P, Haapalahti M, Karttunen T, et al. Prevalence of celiac disease among children in Finland. NEngl J Med 2003;348:25172524. DOI: 10.1056/NEJMoa021687

9. Ventura A, Magazzu G, Greco L. Duration of exposure to gluten and risk for autoimmune disorders in patients with celiac disease. SIGEP Study Group for autoimmune disorders in celiac disease. Gastroenterology 1999;117:297-303. DOI: 10.1053/ gast.1999.0029900297

10. Smedby KE, Akerman M, Hildebrand H, Glimelius B, Ekbom A, Askling J . Malignant lymphomas in coeliac disease: evidence of increased risks for lymphoma types other than enteropathy-type T cell lymphoma. Gut 2005;54:54-59.

11. Viljamaa M, Kaukinen K, Pukkala E, Hervonen K, Reunala T, Collin P. Malignancies and mortality in patients with coeliac disease and dermatitis herpetiformis: 30-year population-based study. Dig Liver Dis 2006; 38:374-380.

12. Gao Y, Kristinsson SY, Goldin LR, Björkholm M, Caporaso NE, Landgren O. Increased risk for non-Hodgkin lymphoma in individuals with celiac disease and a potential familial association. Gastroenterology 2009;136: 91-98. DOI: 10.1053/j.gastro.2008.09.031

13. Goldacre MJ, Wotton CJ, Yeates D, Seagroatt V, Jewell D. Cancer in patients with ulcerative colitis, Crohn's disease and coeliac disease: record linkage study. Eur J Gastroenterol Hepatol 2008;20:297-304.

14. Karell K, Louka AS, Moodie SJ, Ascher H, Clot F, Greco L et al. HLA types in celiac disease patients not carrying the DQA1*05-DQB1*02 (DQ2) heterodimer: results from the European Genetics Cluster on Celiac Disease. Hum Immunol 2003; 64: 469-477.

15. Hue S, Mention JJ, Monteiro RC, Zhang S, Cellier C, Schmitz J et al. A direct role for NKG2D/MICA interaction in villous atrophy during celiac disease. Immunity 2004; 21: 367-377.

16. Cinova J, Palova-Jelinkova L, Smythies LE, Cerna M, Pecharova B, Dvorak M, et al. Gliadin peptides activate blood monocytes from patients with celiac disease. J Clin Immunol 2007; 27: 201-209.

17. Nikulina M, Habich C, Flohe SB, Scott FW, Kolb H. Wheat gluten causes dendritic cell maturation and chemokine secretion. J Immunol 2004; 173: 1925-1933. DOI: 10.4049/jimmunol.173.3.1925

18. Molberg O, McAdam SN, Korner R, Quarsten H, Kristiansen $\mathrm{C}$, Madsen $\mathrm{L}$, et al. Tissue transglutaminase selectively modifies gliadin peptides that are recognized by gut-derived T cells in celiac disease. Nat Med 1998; 4: 713-717.

19. Vader LW, de Ru A, van der Wal Y, Kooy YM, Benckhuijsen W, Mearin ML et al. Specificity of tissue transglutaminase explains cereal toxicity in celiac disease. $J$ Exp Med 2002; 195: 643-649.

20. Hausch F, Shan L, Santiago NA, Gray GM, Khosla C. Intestinal digestive resistance of immunodominant gliadin peptides. Am J Physiol Gastrointest Liver Physiol 2002; 283: G996-G1003.

21. Shan L, Molberg O, Parrot I, Hausch F, Filiz F, Gray GM et al. Structural basis for gluten intolerance in celiac sprue. Science 2002; 297: 2275-2279.

22. Smecuol E, Bai JC, Vazquez H, Kogan Z, Cabanne A, Niveloni S et al. Gastrointestinal permeability in celiac disease. Gastroenterology 1997; 112: 1129-1136.

23. Kurppa K, Collin P, Viljamaa M, Haimila K, Saavalainen $\mathrm{P}$, Partanen J, et al. Diagnosing mild enteropathy celiac disease: a randomized, controlled clinical study. Gastroenterology 2009; 136: 816-23. DOI: 10.1053/j.gastro.2008.11.040

24. See J, Murray JA. Gluten-free diet: the medical and nutrition management of celiac disease. Nutr Clin Pract 2006; 21: 1-15.

25. Rubio-Tapia A, Murray JA. Celiac disease. Curr Opin Gastroenterol 2010; 26: 116-122.

26. Sollid LM, Lundin KE. Diagnosis and treatment of celiac disease. Mucosal Immunol 2009; 2: 3-7. DOI: 10.1038/mi.2008.74

27. Holmes GK, Prior P, Lane MR, Pope D, Allan RN. Malignancy in coeliac disease-effect of a gluten free diet. Gut 1989; 30: 333-338.

28. Catassi C, Fabiani E, Iacono G, D’Agate C, Francavilla $\mathrm{R}$, Biagi F, et al. A prospective, double-blind, placebocontrolled trial to establish safe gluten threshold for patients with celiac disease. Am J Clin Nutri 2007; 85: 160-166. 
29. Peraaho M, Kaukinen K, Paasikivi K, Sievanen H, Lohiniemi S, Maki M, et al. Wheat-starch-based glutenfree products in the treatment of newly detected coeliac disease: prospective and randomized study. Aliment Pharmacol Ther 2003; 17: 587-594.

30. Lee A, Newman JM. Celiac diet: its impact on quality of life. J Am Diet Assoc 2003; 103: 1533-5.

31. Hall NJ, Rubin G, Charnock A. Systematic review: adherence to a gluten-free diet in adult patients with coeliac disease. Aliment Pharmacol Ther 2009; 30: 315-30.

32. Thompson T, Lee AR, Grace T. Gluten contamination of grains, seeds, and flours in the United States: a pilot study. J Am Diet Assoc 2010; 110: 937 -40.

33. Thompson T, Mendez E. Commercial assays to assess gluten content of gluten-free foods: why they are not created equal. J Am Diet Assoc 2008; 108: 1682-1687.

34. Thorsby E: A short history of HLA. Tissue Antigens 2009, 74:101-116. DOI: 10.1111/j.1399-0039.2009.01291.x.

35. Thorsby E: On the future of HLA. Tissue Antigens 2011, 78:229-240. DOI: 10.1111/j.1399-0039.2011.01770.x.

36. Megiorni F, Pizzuti A. HLA-DQA1 and HLA-DQB1 in Celiac disease predisposition: practical implications of the HLA molecular typing. J Biomed Sci 2012; 19:88. DOI: 10.1186/1423-0127-19-88

37. Kagnoff MF. Celiac Disease: pathogenesis of a model immunogenetic disease. J. Clin. Invest. 2007;117:4149. DOI: $10.1172 / \mathrm{JCI} 30253$

38. Bevan S, Popat S, Braegger CP, Busch A, O'Donoghue $\mathrm{D}$, Falth-Magnusson $\mathrm{K}$, et al. Contribution of the MHC region to the familial risk of celiac disease. J Med Genet 1999;36:687-690.

39. Lundin KEA, Scott H, Hansen T, Paulsen G, Halstensen TS, Fausa O, et al. Gliadin-specific, HLA DQ (alpha $1 * 0501$, beta $1 * 0201$ ) restrict $T$ cells isolated from the small intestinal mucosa of celiac disease patients. $J$ Exp Med. 1993;178:187-196.

40. Polvi A, Arranz E, Fernandez-Arquero M, Collin P, Mäki M, Sanz A, et al. HLA-DQ2-negative celiac disease in Finland and Spain. Human Immunol. 1998;59:169-175.

41. Farre CÂ, Humber P, Vilar P, Varea V, Aldeguer X, Carnicer J, et al. Serological MarKers and HLA-D2 Haplotype among first-degree relatives of celiac patients. Dig Dis Sci.1999;11:2344-2349.

42. Bonamico M, Ferri M, Mariani P Nenna R, Thanasi E, Luparia RP, et al. Serologic and genetic markers of celiac disease: a sequential study in the screening of first degree relatives. J Pediatr Gastroenterol Nutr. 2006;42:150154.

43. Sollid LM. Molecular Basis of celiac disease. Ann Rev Immunol. 2000;18:53-81.

44. Babron $\mathrm{MC}$, Nilsson $\mathrm{S}$, Adamovic S, et al. Meta and pooled analysis of European coeliac disease data. Eur $J$ Hum Genet 2003;11:828-834.

45. Greco L, Corazza G, Babron MC, Clot F, FulchignoniLataud MC, Percopo S, et al. Genome search in celiac disease. Am J Hum Genet 1998;62:669-675.

46. Liu J, Juo SH, Holopainen P, Terwilliger J, Tong X, Grunn A, et al. Genomewide linkage analysis of celiac disease in Finnish families. Am J Hum Genet 2002; 70:51-59.

47. Naluai AT, Nilsson S, Gudjonsdottir AH, Louka AS, Ascher H, Ek J, et al. Genome-wide linkage analysis of Scandinavian affected sib-pairs supports presence of susceptibility loci for celiac disease on chromosomes 5 and 11. Eur J Hum Genet 2001;9:938-944.

48. Djilali-Saiah I, Schmitz J, Harfouch-Hammoud E, Mougenot JF, Bach JF, Caillat-Zucman S. CTLA-4 gene polymorphism is associated with predisposition to celiac disease. Gut 1998;43:187-189.

49. Haimila K, Einarsdottir E, de Kauwe A, Koskinen LL, Pan-Hammarström Q, Kaartinen T, et al. The shared CTLA4- ICOS risk locus in celiac disease, IgA deficiency and common variable immunodeficiency. Genes Immun 2009;10:151-161.

50. van Belzen MJ, Mulder CJ, Zhernakova A, Pearson PL, Houwen RH, Wijmenga C, et al. CTLA4_49 A/G and CT60 polymorphisms in Dutch coeliac disease patients. Eur J Hum Genet 2004;12:782-785.

51. Monsuur AJ, de Bakker PI, Alizadeh BZ, Zhernakova A, Bevova MR, Strengman E, et al. Myosin IXB variant increases the risk of celiac disease and points toward a primary intestinal barrier defect. Nat Genet 2005;37:1341-1344.

52. Woolley N, Holopainen P, Ollikainen V, Mustalahti K, Maki M, Kere J, et al. A new locus for coeliac disease mapped to chromosome 15 in a population isolate. Hum Genet 2002;111:40-45.

53. Hunt KA, Zhernakova A, Turner G, Heap GA, Franke L, Bruinenberg $\mathrm{M}$, et al. Newly identified genetic risk variants for celiac disease related to the immune response. Nat Genet 2008;40:395-402. 
54. van Heel DA, Franke L, Hunt KA, Gwilliam R, Zhernakova $\mathrm{A}$, Inouye $\mathrm{M}$, et al. A genome-wide association study for celiac disease identifies risk variants in the region harboring IL2 and IL21. Nat Genet 2007;39:827-829. DOI: $10.1038 / \mathrm{ng} 2058$

55. Adamovic S, Amundsen SS, Lie BA, Gudjonsdottir A.H., Ascher H., Ek J., van Heel D.A, et al. Association study of IL2/IL21 and FcgRIIa: significant association with the IL2/IL21 region in Scandinavian coeliac disease families. Genes Immun 2008;9:364-367.

56. Garner CP, Murray JA, Ding YC, Tien Z, van Heel DA, Neuhausen SL. Replication of celiac disease UK genome-wide association study results in a US population. Hum Mol Genet 2009; 18:4219-4225.

57. Romanos J, Barisani D, Trynka G, Zhernakova A, Bardella MT, Wijmenga C, et al. Six new coeliac disease loci replicated in an Italian population confirm association with coeliac disease. J Med Genet 2009;46:60-63.

58. Koskinen LL, Einarsdottir E, Dukes E, Heap GA, Dubois P, Korponay-Szabo IR, et al. Association study of the IL18RAP locus in three European populations with coeliac disease. Hum Mol Genet 2009;18:1148-1155.

59. Dema B, Martinez A, Fernandez-Arquero M, Maluenda C, Polanco I, de la Concha EG, et al. Association of IL18RAP and CCR3 with celiac disease in the Spanish population. J Med Genet 2009;46:617-619.

60. Lundin KE, Scott H, Hansen T, Paulsen G, Halstensen TS, Fausa O, et al: Gliadinspecific, HLA-DQ (alpha $1 * 0501$, beta $1 * 0201$ ) restricted $T$ cells isolatedfrom the small intestinal mucosa of celiac disease patients. $J$ Exp Med 1993; 178:187-196. DOI: 10.1084/jem.178.1.187

61. Henderson KN, Tye-Din JA, Reid HH, Chen Z, Borg NA, Beissbarth T, et al: A structural and immunological basis for the role of human leukocyte antigen DQ8 in celiac disease. Immunity 2007; 27:23-34. DOI: 10.1016/j. immuni.2007.05.015

62. Bergseng E, Sidney J, Sette A, Sollid LM: Analysis of the binding of gluten T-cell epitopes to various human leukocyte antigen class II molecules. Hum Immunol 2008; 69:94-100.

63. Fallang LE, Bergseng E, Hotta K, Berg-Larsen A, Kim CY, Sollid LM: Differences in the risk of celiac disease associated with HLA-DQ2.5 or HLA-DQ2.2 are related to sustained gluten antigen presentation. Nat Immunol 2009; 10:1096-1101.

64. Molberg O, Mcadam SN, Körner R, Quarsten H, Kris- tiansen C, Madsen L, et al: Tissue transglutaminase selectively modifies gliadin peptides that are recognized by gut-derived T cells in celiac disease. Nat Med 1998; 4:713-717. DOI: $10.1038 / \mathrm{nm} 0698-713$

65. Abadie V, Sollid LM, Barreiro LB, Jabri B: Integration of genetic and immunological insights into a model of celiac disease pathogenesis. Annu Rev Immunol 2011, 29:493-525.

66. Tollefsen S, Arentz-Hansen H, Fleckenstein B, Molberg O, Ráki M, et al: HLADQ2 and -DQ8 signatures of gluten T cell epitopes in celiac disease. J Clin Invest 2006; 116:2226-2236.

67. Bodd M, Kim CY, Lundin KE, Sollid LM: T-Cell Response to Gluten in Patients With HLA-DQ2.2 Reveals Requirement of Peptide-MHC Stability in Celiac Disease. Gastroenterology 2012, 142:552-561.

68. Tollefsen S, Hotta K, Chen X, Simonsen B, Swaminathan $\mathrm{K}$, Mathews II, et al: Structural and functional studies of the trans-encoded HLA-DQ2.3 (DQA1*03:01/ DQB1*02:01) molecule. J Biol Chem 2012, 287:1361113619.

69. Ludvigsson JF, Green PH: Clinical management of coeliac disease. J Intern Med 2011, 269:560-571.

70. Megiorni F, Mora B, Bonamico M, Nenna R, Di Pierro $\mathrm{M}$, Catassi $\mathrm{C}$, et al: A rapid and sensitive method to detect specific human lymphocyte antigen (HLA) class II alleles associated with celiac disease. Clin Chem Lab Med 2008, 46:193-196.

71. Joda H, Beni V, Curnane D, Katakis I, Alakulppi N, Lind $\mathrm{K}$, et al: Low-medium resolution HLA-DQ2/DQ8 typing for coeliac disease predisposition analysis by colorimetric assay. Anal Bioanal Chem 2012, 403:807-819.

72. Bourgey M, Calcagno G, Tinto N, Gennarelli D, Margaritte-Jeannin $\mathrm{P}$, Troncone R, et al: HLA related genetic risk for coeliac disease. Gut 2007, 56:1054-1059.

73. Megiorni F, Mora B, Bonamico M, Barbato M, Nenna $\mathrm{R}$, Maiella G, et al: HLA-DQ and risk gradient for celiac disease. Hum Immunol 2009, 70:55-59.

74. Hill ID, Dirks MH, Liptak GS, Colletti RB, Fasano A, Guandalini S, et al: Guideline for the diagnosis and treatment of celiac disease in children: recommendations of the North American Society for Pediatric Gastroenterology, Hepatology and Nutrition. J Pediatr Gastroenterol Nutr 2005, 40:1-19.

75. Liu E, Rewers M, Eisenbarth GS: Genetic testing: who should do the testing and what is the role of genetic test- 
ing in the setting of celiac disease? Gastroenterology 2005, 128:S33-S37.

76. Dieterich W, Ehnis T, Bauer M, Donner P, Volta U, Riecken EO, et al. Identification of tissue transglutaminase as the autoantigen of celiac disease. Nat Med 1997;3:797-801.

77. Elli L, Bergamini CM, Bardella MT, Schuppan D . Transglutaminases in inflammation and fibrosis of the gastrointestinal tract and the liver. Dig Liver Dis 2009;41:541-550.

78. Schuppan D, Dieterich W, Ehnis T, Bauer M, Donner P, Volta $\mathrm{U}$, et al. Identification of the autoantigen of celiac disease. Ann N Y Acad Sci 1998;859:121-126.

79. Cinova J, Palova-Jelinkova L, Smythies LE, Cerna M, Pecharova B, Dvorak M, et al. Gliadin peptides activate blood monocytes from patients with celiac disease. J Clin Immunol 2007;27:201-209.

80. Maiuri L, Ciacci C, Ricciardelli I, Vacca L, Raia V, Auricchio S, et al. Association between innate response to gliadin and activation of pathogenic $\mathrm{T}$ cells in coeliac disease. Lancet 2003;362:30 - 37.

81. Palova-Jelinkova L, Rozkova D, Pecharova B, Bartova J, Sediva A, Tlaskalova-Hogenova, et al. Gliadin fragments induce phenotypic and functional maturation of human dendritic cells. J Immunol 2005;175:7038 -7045.

82. Tuckova L, Novotna J, Novak P, Flegelova Z, Kveton T, Jelinkova $\mathbf{L}$, et al. Activation of macrophages by gliadin fragments: isolation and characterization of active peptide. J Leukoc Biol 2002;71:625- 631.

83. Thomas KE, Sapone A, Fasano A, Vogel S.N. Gliadin stimulation of murine macrophage inflammatory gene expression and intestinal permeability are MyD88dependent: role of the innate immune response in Celiac disease. J Immunol 2006;176:2512-2521.

84. Hue S, Mention JJ, Monteiro RC, Zhang S, Cellier C, Schmitz J, et al . A direct role for NKG2D/ MICA interaction in villous atrophy during celiac disease. Immunity 2004;21:367-377. DOI: 10.1016/j.immuni.2004.06.018.

85. Meresse B, Chen Z, Ciszewski C, Tretiakova M, Bhagat G, Krausz TN, et al. Coordinated induction by IL15 of a TCR-independent NKG2D signaling pathway converts CTL into lymphokine-activated killer cells in celiac disease. Immunity 2004;21:357-366. DOI: 10.1016/j. immuni.2004.06.020

86. Di Sabatino A, Ciccocioppo R, Cupelli F, B Cinque, D Millimaggi, M M Clarkson, et al. Epithelium derived interleukin 15 regulates intraepithelial lymphocyte Th1 cytokine production, cytotoxicity, and survival in coeliac disease. Gut 2006;55:469 - 477. DOI: 10.1136/ gut.2005.068684

87. Benahmed M, Meresse B, Arnulf B, Barbe U, Mention $\mathrm{JJ}$, Verkarre $\mathrm{V}$, et al. Inhibition of TGF-beta signaling by IL-15: a new role for IL-15 in the loss of immune homeostasis in celiac disease. Gastroenterology 2007;132: 994-1008

88. Bernardo D, Garrote JA, Allegretti Y, León A, Gómez E, Bermejo-Martin JF, et al. Higher constitutive IL15R alpha expression and lower IL-15 response threshold in coeliac disease patients. Clin Exp Immunol 2008;154:64 -73. DOI: 10.1111/j.1365-2249.2008.03743.x.

89. Maiuri L, Ciacci C, Auricchio S, et al. Interleukin 15 mediates epithelial changes in celiac disease. Gastroenterology 2000;119:996-1006.

90. Mention JJ, Ben Ahmed M, Begue B, et al. Interleukin 15: a key to disrupted intraepithelial lymphocyte homeostasis and lymphomagenesis in celiac disease. Gastroenterology 2003;125:730 -745. DOI: 10.1016/ S0016-5085(03)01047-3.

91. Meresse B, Verdier J, Cerf-Bensussan N. The cytokine interleukin 21: a new player in coeliac disease? Gut 2008;57:879 -881. DOI: 10.1136/gut.2007.141994

92. Yadav P, Das P, Mirdha BR, Gupta SD, Bhatnagar S, Pandey RM, et al. Current spectrum of malabsorption syndrome in adults in India. Indian J Gastroenterol 2011;30:22-28. DOI 10.1007/s12664-011-0081-0

93. Snyder CL, Young DO, Green PHR, Taylor AK. Celiac disease. Gene Rev 2008.

94. Feldman M. The origin of cultivated wheat. In: Bonjean AP, Angus WJ, editors. The World Wheat Book. London: Intercept, 2001: 1-56.

95. Auricchio S, De Ritis G, De Vincenzi M, Occorsio P, Silano $\mathrm{V}$. Effects of gliadinderived peptides from bread and durum wheats on small intestinal cultures from rat fetus and celiac children. Pediatr Res 1982;16:1004-1010. DOI: 10.1203/00006450-198212000-00006.

96. Frisoni M, Corazza GR, Lafiandra D, De Ambrogio E, Filipponi $\mathrm{C}$, et al. Wheat deficient in gliadins: promising tool for treatment of coeliac disease. Gut 1995;36:375-378.

97. Molberg O, Uhlen AK, Jensen T, Flaete NS, Fleckenstein $\mathrm{B}$, Arentz-Hansen $\mathrm{H}$, et al. Mapping of gluten T-cell epitopes in the bread wheat ancestors: implications for celiac disease. Gastroenterology 2005;128:393- 401. 
98. van Herpen TW, Goryunova SV, van der Schoot J, Mitreva $\mathrm{M}$, Salentijn $\mathrm{E}$, Vorst $\mathrm{O}$, et al. Alpha-gliadin genes from the A, B, and D genomes of wheat contain different sets of celiac disease epitopes. BMC Genomics 2006;7:1. DOI: 10.1186/1471-2164-7-1.

99. van den Broeck HC, van Herpen TW, Schuit C, Salentijn EM, Dekking L, et al. Removing celiac disease-related gluten proteins from bread wheat while retaining technological properties: a study with Chinese Spring deletion lines. BMC Plant Biol 2009;9:41. DOI: 10.1186/14712229-9-41

100. Di Cagno R, De Angelis M, Lavermicocca P, De Vincenzi M, Giovannini C, Faccia M, et al. Proteolysis by sourdough lactic acid bacteria: effects on wheat flour protein fractions and gliadin peptides involved in human cereal intolerance. Appl Environ Microbiol 2002;68:623-633.

101. Rizzello CG, De Angelis M, Di Cagno R, Camarca A, Silano M, Losito I, et al. Highly efficient gluten degradation by lactobacilli and fungal proteases during food processing: new perspectives for celiac disease. Appl Environ Microbiol 2007;73:4499 - 4507. DOI: 10.1128/ AEM.00260-07.

102. De Angelis M, Rizzello CG, Fasano A, Clemente MG, de Simone C, Silano M, et al. VSL\#3 probiotic preparation has the capacity to hydrolyze gliadin polypeptides responsible for Celiac Sprue. Biochim Biophys Acta 2006;1762:80 -93

103. Di Cagno R, De Angelis M, Auricchio S, Greco L, Clarke C, De Vincenzi M, et al. Sourdough bread made from wheat and nontoxic flours and started with selected lactobacilli is tolerated in celiac sprue patients. Appl Environ Microbiol 2004;70:1088 -1096. DOI: 10.1128/ AEM.70.2.1088-1096.2004

104. Kiyosaki T, Matsumoto I, Asakura T, Funaki J, Kuroda M, Misaka T, et al. Gliadain, a gibberellin-inducible cysteine proteinase occurring in germinating seeds of wheat, Triticum aestivum L., specifically digests gliadin and is regulated by intrinsic cystatins. FEBS J2007;274:1908-1917.

105. Gianfrani C, Siciliano RA, Facchiano AM, Camarca A, Mazzeo MF, Costantini S, et al. Transamidation of wheat flour inhibits the response to gliadin of intestinal T cells in celiac disease. Gastroenterology 2007;133:780 -789. DOI: 10.1053/j.gastro.2007.06.023.

106. Yokoyama K, Nio N, Kikuchi Y. Properties and applications of microbial transglutaminase. Appl Microbiol Biotechnol 2004; 64:447-454.
107. Cabrera-Chavez F, Rouzaud-Sandez O, Sotelo-Cruz N, Calderon de la Barca AM. Transglutaminase treatment of wheat and maize prolamins of bread increases the serum IgA reactivity of celiac disease patients. J Agric Food Chem 2008;56:1387-1391. DOI: 10.1021/jf0724163.

108. Cabrera-Chavez F, Rouzaud-Sandez O, Sotelo-Cruz N, Calderon de la Barca AM. Bovine milk caseins and transglutaminase-treated cereal prolamins are differentially recognized by IgA of celiac disease patients according to their age. J Agric Food Chem 2009;57: 3754 -3759.

109. Shan L, Molberg O, Parrot I, Hausch F, Filiz F, Gray GM, et al. Structural basis for gluten intolerance in celiac sprue. Science 2002;297:2275-2279. DOI: 10.1126/ science. 1074129

110. Hausch F, Shan L, Santiago NA, Gray GM, Khosla C, et al. Intestinal digestive resistance of immunodominant gliadin peptides. Am J Physiol Gastrointest Liver Physiol 2002;283:G996-G1003.

111. Mamone G, Ferranti P, Rossi M, et al. Identification of a peptide from alpha-gliadin resistant to digestive enzymes: implications for celiac disease. J Chromatogr B Analyt Technol Biomed Life Sci 2007;855:236 -241.

112. Marti T, Molberg O, Li Q, Gray GM, Khosla C, Sollid LM. Prolyl endopeptidase-mediated destruction of T cell epitopes in whole gluten: chemical and immunological characterization. J Pharmacol Exp Ther 2005; 312:19-26.

113. Cornell HJ, Macrae FA, Melny J, Pizzey, C.J., Cook, F., Mason, S, et al. Enzyme therapy for management of coeliac disease. Scand J Gastroenterol 2005; 40:1304 -1312 .

114. Stepniak D, Spaenij-Dekking L, Mitea C, Moester M, de $\mathrm{Ru}$ A, Baak-Pablo R, et al. Highly efficient gluten degradation with a newly identified prolyl endoprotease: implications for celiac disease. Am J Physiol Gastrointest Liver Physiol 2006;291:G621-G629. DOI: 10.1152/ ajpgi.00034.2006

115. Mitea C, Havenaar R, Drijfhout JW, Edens L, Dekking L, Koning F. Efficient degradation of gluten by a prolyl endoprotease in a gastrointestinal model: implications for coeliac disease. Gut 2008;57:25-32. DOI: 10.1136/ gut.2006.111609

116. Pyle GG, Paaso B, Anderson BE, Allen DD, Marti T, Li $\mathrm{Q}$, et al. Effect of pretreatment of food gluten with prolyl endopeptidase on gluten-induced malabsorption in celiac sprue. Clin Gastroenterol Hepatol 2005;3:687-694. DOI: 10.1016/S1542-3565(05)00366-6. 
117. Pyle GG, Paaso B, Anderson BE, Allen D, Marti T, Khosla $\mathrm{C}$, et al. Low-dose gluten challenge in celiac sprue: malabsorptive and antibody responses. Clin Gastroenterol Hepatol 2005;3:679 - 686.

118. Stepniak D, Spaenij-Dekking L, Mitea C, Moester M, de Ru A, Baak-Pablo R, et al. Highly efficient gluten degradation with a newly identified prolyl endoprotease: implications for celiac disease. Am J Physiol Gastrointest Liver Physiol 2006;291:G621-G629.

119. Mitea C, Havenaar R, Drijfhout JW, Edens L, Dekking L, Koning F. Efficient degradation of gluten by a prolyl endoprotease in a gastrointestinal model: implications for coeliac disease. Gut 2008;57:25-32.

120. Fasano A, Not T, Wang W, Uzzau S, Berti I, Tommasini A, et al. Zonulin, a newly discovered modulator of intestinal permeability, and its expression in coeliac disease. Lancet 2000; 355: 1518-1519.

121. Wang W, Uzzau S, Goldblum SE, Fasano A. Human zonulin, a potential modulator of intestinal tight junctions. J Cell Sci 2000; 113(Pt 24): 4435-4440.

122. Fasano A, Uzzau S. Modulation of intestinal tight junctions by Zonula occludens toxin permits enteral administration of insulin and other macromolecules in an animal model. J Clin Invest 1997; 99: 1158-1164.

123. Tripathi A, Lammers KM, Goldblum S, Shea-Donohue T, Netzel-Arnett S, Buzza MS, et al. Identification of human zonulin, a physiological modulator of tight junctions, as prehaptoglobin-2.Proc Natl Acad Sci USA 2009; 106: 16799-16804.

124. Paterson BM, Lammers KM, Arrieta MC, Fasano A, Meddings JB. The safety, tolerance, pharmacokinetic and pharmacodynamic effects of single doses of AT-1001 in coeliac disease subjects: a proof of concept study. Aliment Pharmacol Ther 2007;26:757-766.

125. Choi K, Siegel M, Piper JL, Yuan L, Cho E, Strnad P, et al. Chemistry and biology of dihydroisoxazole derivatives: selective inhibitors of human transglutaminase 2. Chem Biol 2005;12:469-475.

126. Lai TS, Slaughter TF, Peoples KA, Hettasch J.M., Greenberg C.S. Regulation of human tissue transglutaminase function by magnesium-nucleotide complexes. Identification of distinct binding sites for Mg-GTP and Mg-ATP. J Biol Chem 1998;273:1776 -1781.

127. Siegel M, Khosla C. Transglutaminase 2 inhibitors and their therapeutic role in disease states. Pharmacol Ther 2007;115:232-245. DOI: 10.1016/j.phar- mthera.2007.05.003

128. Watts T, Berti I, Sapone A, Gerarduzzi T, Not T, Zielke $\mathrm{R}$, et al. Role of the intestinal tight junction modulator zonulin in the pathogenesis of type I diabetes in BB diabetic-prone rats. Proc Natl Acad Sci USA 2005;102:2916-2921.

129. Jeitner TM, Delikatny EJ, Ahlqvist J, Capper H, Cooper AJL, et al. Mechanism for the inhibition of transglutaminase 2 by cystamine. Biochem Pharmacol 2005;69:961-970.

130. Pardin C, Roy I, Lubell WD, Keillor JW, et al. Reversible and competitive cinnamoyl triazole inhibitors of tissue transglutaminase. Chem Biol Drug Des 2008;72:189 -196. DOI: 10.1111/j.1747-0285.2008.00696.x

131. de Macedo P, Marrano C, Keillor JW. Synthesis of dipeptidebound epoxides and alpha,beta-unsaturated amides as potential irreversible transglutaminase inhibitors. Bioorg Med Chem 2002;10:355-360.

132. Hausch F, Halttunen T, Maki M, Khosla C. Design, synthesis, and evaluation of gluten peptide analogs as selective inhibitors of human tissue transglutaminase. Chem Biol 2003;10:225-231.

133. Molberg O, McAdam S, Lundin KE, Kristiansen $\mathrm{C}$, Arentz-Hansen $\mathrm{H}$, Kett $\mathrm{K}$, et al. T cells from celiac disease lesions recognize gliadin epitopes deamidated in situ by endogenous tissue transglutaminase. Eur J Immunol 2001; 31:1317-1323. DOI: 10.1002/1521-4141(200105)31:5<1317::AIDIMMU1317>3.0.CO;2-I

134. Maiuri L, Ciacci C, Ricciardelli I, Vacca, V. Raia, A. Rispo, et al. Unexpected role of surface transglutaminase type II in celiac disease. Gastroenterology 2005;129:1400 -1413. DOI: 10.1053/j.gastro.2005.07.054

135. Anderson RP, van Heel DA, Tye-Din JA, Jewell DP, Hill AV. Antagonists and non-toxic variants of the dominant wheat gliadin T cell epitope in coeliac disease. Gut 2006;55:485- 491.

136. Xia J, Siegel M, Bergseng E, Sollid LM, Khosla C. Inhibition of HLA-DQ2-mediated antigen presentation by analogues of a high affinity 33-residue peptide from alpha2-gliadin. J Am Chem Soc 2006;128:1859 -1867. DOI: $10.1021 / \mathrm{ja} 056423 \mathrm{o}$

137. Rubio-Tapia A, Talley NJ, Gurudu SR, Wu T.T., Murray J.A. Gluten-free diet and steroid treatment are effective therapy for most patients with collagenous sprue. Clin Gastroenterol Hepatol 2010; 8: 344-9. 
138. Ciacci C, Maiuri L, Russo I, R.Tortora, C.Bucci, C. Cappello, et al. Efficacy of budesonide therapy in the early phase of treatment of adult coeliac disease patients with malabsorption: an in vivo/in vitro pilot study. Clin Exp Pharmacol Physiol 2009; 36: 1170-6. DOI: 10.1111/j.1440-1681.2009.05211.x

139. Jamma S, Leffler DA, Dennis M, Najarian RM, Schuppan DB, Sheth $\mathbf{S}$, et al. Small intestinal release mesalamine for the treatment of refractory celiac disease type I. J Clin Gastroenterol 2011; 45: 30-3.

140. Green PH, Cellier C. Celiac disease. NEngl J Med 2007; 357: 1731-43.

141. Yokoyama S, Watanabe N, Sato N, Perera PY, Filkoski L, Tanaka T, et al. Antibody-mediated blockade of IL15 reverses the autoimmune intestinal damage in transgenic mice that overexpress IL-15 in enterocytes. Proc
Natl Acad Sci USA 2009; 106: 15849-54. DOI: 10.1073/ pnas.0908834106

142. Malamut G, El Machhour R, Montcuquet N, Martin-Lanneree S, Dusanter-Fourt I, Verkarre V, et al. IL-15 triggers an antiapoptotic pathway in human intraepithelial lymphocytes that is a potential new target in celiac disease associated inflammation and lymphomagenesis. $J$ Clin Invest 2010; 120: 2131-2143. DOI: 10.1172/JCI41344

143. Booth V, Keizer DW, Kamphuis MB, Clark-Lewis, I., and Sykes, B.D. The CXCR3 binding chemokine IP-10/ CXCL10: structure and receptor interactions. Biochemistry 2002; 41: 10418-10425.

144. Rashtak S, Marietta EV, Murray JA. Gliadin stimulation of monocytes leads to increased expression of multiple T cell recruiting chemokines: a novel innate immune response. Clin Immunol 2010; 135 (Suppl. S): S47. 